Proc. Estonian Acad. Sci. Biol. Ecol., 2005, 54, 1, 5-17

\title{
Water level and water temperature as factors determining phytoplankton biomass and nutrient content in Lake Peipsi
}

\author{
Anu Milius*, Reet Laugaste, Tõnu Möls, Marina Haldna, \\ and Külli Kangur
}

\begin{abstract}
Institute of Zoology and Botany, Estonian Agricultural University, Riia 181, 51014 Tartu, Estonia; reet@zbi.ee; tonu@zbi.ee; marina@zbi.ee; kkangur@zbi.ee
\end{abstract}

Received 4 August 2004, in revised form 30 November 2004

\begin{abstract}
This paper investigates, using mainly data of 1985-2003, the influence of water temperature and water level on nutrients and on most important phytoplankton groups in Lake Peipsi. The water environment characteristics (water level at sampling time, in spring, in autumn, in the whole sampling year, and in the previous year, and the corresponding water temperatures) were considered as potential factors determining nutrient and phytoplankton fluctuations in the lake. To overcome problems with statistical correlation between environmental characteristics, these were linearly combined into a single Water Condition Factor (WCF). This factor was calculated with the Canonical Analysis individually for each nutrient and phytoplankton variable and used then to study how and to which extent different environmental conditions determine the corresponding water variable. It appeared that in the WCF of nutrients the most important role was played by water level characteristics while in the case of phytoplankton biomasses (particularly cyanobacteria) also the water temperature parameters had a significant effect. The water temperature had some effect also on the concentration of dissolved inorganic phosphate and dissolved inorganic nitrogen. In the shallower parts of the lake, lakes Lämmijärv and Pihkva (Pskov), the correlations between WCF and the water variables were higher than in the deepest part of the lake, L. Peipsi s.s.
\end{abstract}

Key words: water level, water temperature, nutrients, phytoplankton, Lake Peipsi.

\section{INTRODUCTION}

It is a well-known fact that nutrients, particularly phosphorus, are generally considered the most important growth-controlling factors involved in algal productivity in lakes. The importance of the nitrogen to phosphorus ratio $\left(\mathrm{N}_{\mathrm{tot}}: \mathrm{P}_{\text {tot }}\right)$ in determining the phytoplankton community is underlined in many works. However, according to Reynolds \& Petersen (2000), there is no reason to suppose that

\footnotetext{
* Corresponding author, milius@zbi.ee
} 
the dominance of phytoplankton biomass by cyanobacteria is a function of nutrient availability. The question about nutrients will not rise before the physical requirements of algae (water temperature, insolation, water immobility) are satisfied. Reynolds \& Petersen (2000) found that if cyanobacteria grow, elevated phosphorus concentrations will support enhanced crops and so will enhance the intensity of the blooms. Whether they grow is not determined by the total phosphorus content in the water, except, perhaps, above what are presumably very low threshold values. The eutrophication process has been studied extensively, but only a few authors treat the effect of weather conditions on the chemical composition of water and phytoplankton abundance in lakes (Mineeva \& Litvinov, 1998; George et al., 2000; Wilander \& Persson, 2001; Carvalho \& Kirika, 2003; Nõges et al., 2003).

Weather affects lake physics (water temperature, water level), chemistry (nutrients), and biota (plankton, fish) both directly and indirectly. Weather-driven changes can exceed or prevent the eutrophication process in a lake (Padisák \& Koncsos, 2002). Comparatively few authors investigate the simultaneous effect of weather conditions and eutrophication process.

Long-term datasets of nutrients and phytoplankton populations of L. Peipsi are valuable for examining how phytoplankton responds to changes in water level and water temperature and, in particular, how climate-driven changes will impact on the phytoplankton and its different groups via nutrients.

In shallow lakes the effect of warm weather is especially strong when it synchronizes with low water level. Nõges et al. (2003) and Padisák \& Koncsos (2002) stressed the increase of internal loading during low water level. Long-time investigations of L. Peipsi (since 1962) show the coherence of high phytoplankton biomass with periods of low water level (Laugaste et al., 2001). However, the 1980s with a high water level were relatively poor in phytoplankton despite the most intensive external load in that period. Taking these facts into consideration, the aim of this work is to prove statistically the effect of water level and temperature on nutrients, total phytoplankton, and its groups with largest biomass (diatoms, cyanobacteria, and cryptophytes).

\section{STUDY SITE}

Lake Peipsi s.l. (3558 $\mathrm{km}^{2}$, mean depth $\left.7.1 \mathrm{~m}\right)$ consists of three parts of different trophic state: moderately eutrophic L. Peipsi s.s. $\left(2611 \mathrm{~km}^{2}\right.$, mean depth $\left.8.3 \mathrm{~m}\right)$, highly eutrophic L. Pihkva (Pskov, $708 \mathrm{~km}^{2}, 3.8 \mathrm{~m}$ ), and narrow shallow L. Lämmijärv $\left(236 \mathrm{~km}^{2}, 2.6 \mathrm{~m}\right)$, which connects the two larger parts. In general, the lake is well mixed by wind: no stratification of temperature, dissolved oxygen, and hydrochemical parameters occurs in the ice-free period. The water-level fluctuations in L. Peipsi are considerable, which causes changes in both the surface area and volume of the lake. During the course of the last 80 years, an amplitude of $3.04 \mathrm{~m}$ has been registered (Eipre, 1983), the average annual range of water-level fluctuations is $1.15 \mathrm{~m}$ (Jaani, 1996). Intensive anthropogenic eutrophication of L. Peipsi started in the 1970s (Starast et al., 2001). The nutrient loading reached 
its maximum in the 1980s and has decreased since 1990 (Kangur et al. 2003). The importance of the littoral area (the area covered with macrophytes) is quite negligible in the primary production of such a large lake: $0.6 \%$ of the area of the Estonian part of the lake is occupied by reeds (Mäemets \& Freiberg, 2004), the other macrophytes cover a slightly larger area (Helle Mäemets, pers. comm.). Thus, the littoral is significant as the prime consumer of nutrients originating from the coastal areas but is not substantial in the life of the open water of such a large lake.

The present paper deals with all parts of L. Peipsi but the bulk of data come from L. Peipsi s.s. and Lämmijärv. For L. Pihkva, which is almost entirely situated in the borders of Russia, the material available since 1992 is very scanty.

The oligo-mesotrophic diatom Aulacoseira islandica (O. Müller) Sim. is characteristic of the cool period, causing strong water-blooms in early spring and autumn every four to six years. The blue-green alga (cyanobacterium) Gloeotrichia echinulata (J. S. Smith) P. Richter and the species of Microcystis, Anabaena, and Aphanizomenon dominate in summer, Aphanizomenon also in autumn, causing water-blooms. Some diatoms (Stephanodiscus binderanus (Kütz.) Krieger, Aulacoseira granulata (Ehr.) Sim., and A. ambigua (O. Müller) Sim.) are abundant in summer as well. Diatoms (BAC) and blue-greens (CY) have commonly the opposite dynamics, particularly in years when one of these groups has considerably high biomass peaks. The phytoplankton biomass (FBM) of L. Peipsi s.s. has three peaks during the vegetation period; in the southern parts of the lake mostly two maxima occur.

\section{MATERIAL AND METHODS}

\section{Sampling}

Water samples for nutrient analysis in L. Peipsi were collected from AprilMay to October-November in 1985-2003. The samples were taken monthly, from a depth of 0.1-1.0 m. Since 1992 all stations were located in the Estonian aquatory of the lake, except for 9 stations in the Russian side of the lake sampled in May 1992, October 2001 and 2002, and in August 2003. Depending on the year, the number of sampling sites varied from 5 to 32. The chemical composition of water (total phosphorus $-\mathrm{P}_{\text {tot }}$, orthophosphate ion $-\mathrm{PO}_{4}-\mathrm{P}$, total nitrogen $-\mathrm{N}_{\text {tot }}$, ammonium ion $-\mathrm{NH}_{4}-\mathrm{N}$, nitrate ion $-\mathrm{NO}_{3}-\mathrm{N}$, nitrite ion $-\mathrm{NO}_{2}-\mathrm{N}$, three last combined as dissolved inorganic nitrogen (DIN)) was analysed in the Institute of Zoology and Botany (IZB) at Estonian Agricultural University during 19851992, and in Tartu Environmental Researchers Ltd, Estonia, during 1992-2003. The data on dissolved inorganic P and N compounds for the period 1970-1984 were taken from the hydrochemistry database of IZB. Data on water temperatures and water level were obtained from periodical issues of the Hydrometeorological Service (Tallinn, Leningrad) and from the Institute of Meteorology and Hydrology of the Estonian Ministry of the Environment.

Phytoplankton summer material (July or August) covers the period from 1985 to 1991. Seasonal samples (May or June, July, and October or November) were 
collected in 1992-1996, monthly samples from May (April) to November in 1997-2003. The methods of collecting and treating hydrochemical and phytoplankton samples are described in detail in Laugaste et al., 2001 and Starast et al., 2001.

\section{Statistical methods}

The water level and temperature parameters are combined to form the Water Condition Factor (WCF). Water temperature was represented in WCF by three characteristics: water temperature in May as spring temperature (WTsp), temperature in October-November as autumn temperature (WTau), and temperature at the sampling time (WTs). Water level was represented by five characteristics: water level at the sampling time (WLs), annual mean water level (WLmean), water level in May as spring water level (WLsp), water level in October-November as autumn water level (WLau), and mean water level in the previous year (WLp).

The water variables under study $\left(\mathrm{P}_{\text {tot }}, \mathrm{PO}_{4}-\mathrm{P}, \mathrm{DIN}, \mathrm{N}_{\text {tot }}, \mathrm{FBM}, \mathrm{CY}, \mathrm{BAC}\right.$, and cryptophytes - CRYP) were used in the statistical analysis as recorded, without any transformation. For statistical analysis we applied classical Canonical Analysis realized in the Cancorr procedure of the statistical package SAS, release 8.2. In this analysis, all the eight water environment parameters were considered as the 'With' variables while the group of 'Var' variables contained only one water variable under consideration. As the number of canonical variables produced in Canonical Analysis equals the minimum number of variables in 'With' and 'Var' groups, the analysis generated only one canonical variable for each of the studied water variables. This canonical variable was called Water Condition Factor and denoted by $\mathrm{WCF}_{\mathrm{Ptot}}$, $\mathrm{WCF}_{\mathrm{FBM}}$, etc. where the subscript shows the water variable in the 'Var' group.

Mathematically the construction of WCF is unique except its sign. We have chosen the sign of WCF so that in the water conditions where the WCF value is higher also the water variable is expected to have a higher value. In other words, the sign of WCF guarantees that correlation between WCF and the water variable will always be positive. On graphs this selection is reflected by the curves of WCF and the corresponding water variable running more or less synchronously. The statistical significance of this synchrony was tested in the SAS Cancorr procedure by the significance of the corresponding eigenvalue.

\section{RESULTS}

\section{Nutrients background}

In the investigation period of 1985-2003, the concentration of nutrients varied in a broad range (Table 1). Despite the higher external load in the 1980s, the $\mathrm{P}_{\text {tot }}$ concentration in the lake was lower than in the 1990s and at the beginning of this century. An overall increasing trend of phosphorus can be observed in L. Lämmijärv and in L. Pihkva during 1985-2003 (Fig. 1). 
Table 1. Content of nutrients and some phytoplankton parameters in L. Peipsi and its parts in $1985-2003$

\begin{tabular}{l|r|c|cc|c|c|c}
\hline \multicolumn{1}{c|}{ Variable } & $n$ & $\begin{array}{c}\text { Geom. } \\
\text { mean }\end{array}$ & $\begin{array}{c}95 \% \text { tolerance } \\
\text { limits }\end{array}$ & $\begin{array}{c}\text { Mean for } \\
\text { L. Peipsi } \\
\text { s.s. }\end{array}$ & $\begin{array}{c}\text { Mean for } \\
\text { L. Lämmi- } \\
\text { järv }\end{array}$ & $\begin{array}{c}\text { Mean for } \\
\text { L. Pihkva }\end{array}$ \\
\hline $\mathrm{P}_{\text {tot }}, \mathrm{mg} \mathrm{P} \mathrm{m}^{-3}$ & 1376 & 41 & 14 & 119 & 35 & 63 & 65 \\
$\mathrm{PO}_{4}-\mathrm{P}, \mathrm{mg} \mathrm{P} \mathrm{m}^{-3}$ & 1392 & 8 & 1 & 62 & 7 & 12 & 11 \\
$\mathrm{~N}_{\text {tot }}, \mathrm{mg} \mathrm{N} \mathrm{m}^{-3}$ & 1360 & 739 & 297 & 1838 & 664 & 907 & 982 \\
$\mathrm{DIN}, \mathrm{mg} \mathrm{N} \mathrm{m}^{-3}$ & 850 & 73 & 13 & 419 & 65 & 121 & 50 \\
$\mathrm{~N}_{\text {tot }}: \mathrm{P}_{\text {tot }}$ & 1353 & 18.0 & 5.5 & 59.0 & 19.3 & 14.6 & 15.2 \\
$\mathrm{FBM}_{\mathrm{gWW} \mathrm{m}} \mathrm{gWW}^{-3}$ & 657 & 5.71 & 0.72 & 45.45 & 4.45 & 10.11 & 13.14 \\
$\mathrm{CY}, \mathrm{gWW} \mathrm{m}^{-3}$ & 611 & 0.933 & 0.021 & 41.468 & 0.625 & 1.991 & 2.238 \\
$\mathrm{BAC}, \mathrm{gWW} \mathrm{m}^{-3}$ & 623 & 2.182 & 0.117 & 40.817 & 1.777 & 3.495 & 5.292 \\
$\mathrm{CRYP}, \mathrm{gWW} \mathrm{m}^{-3}$ & 591 & 0.139 & 0.007 & 2.586 & 0.137 & 0.121 & 0.152
\end{tabular}
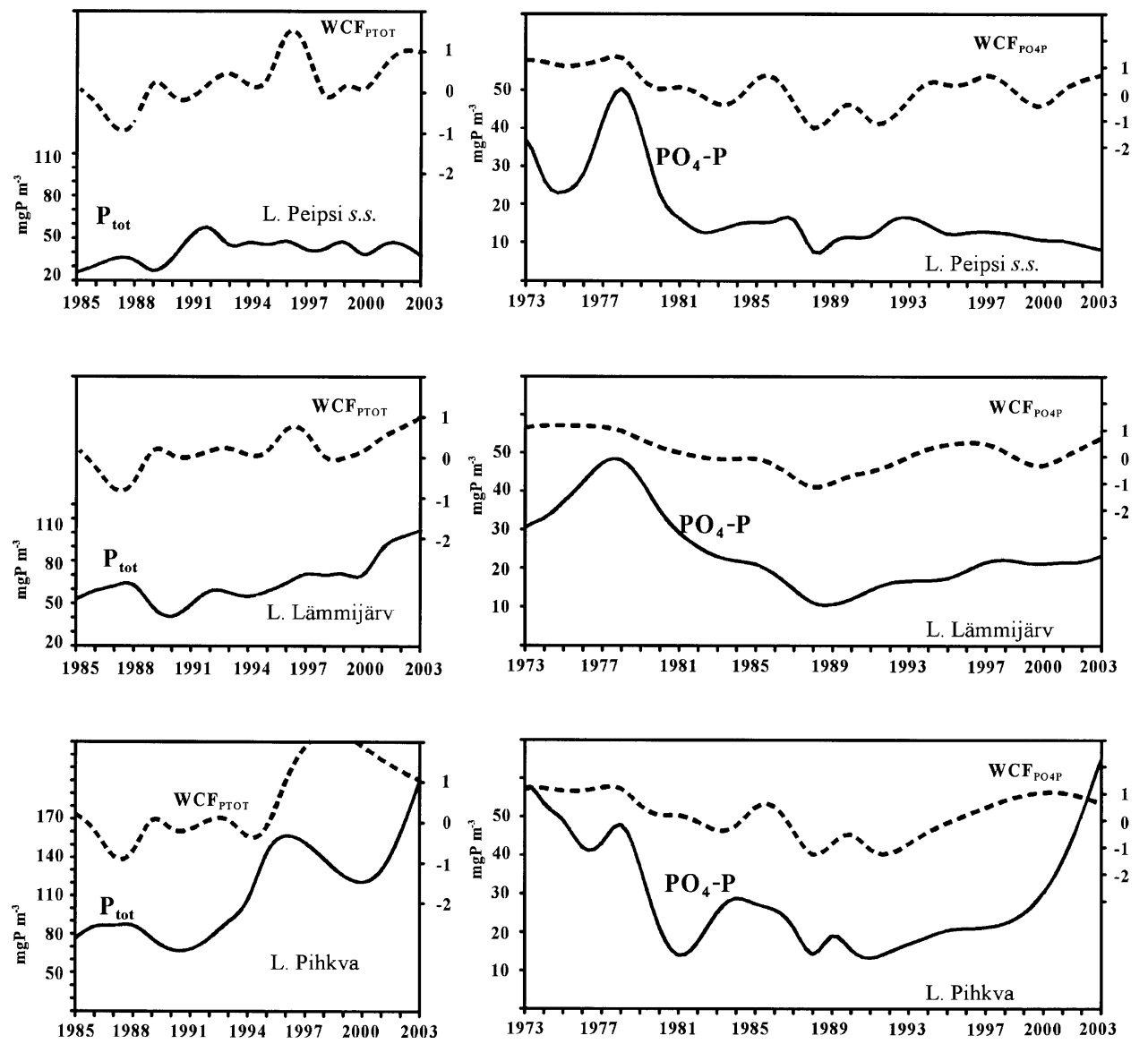

Fig. 1. Dynamics of WCF and the corresponding total and mineral phosphorus content in the lake parts. 
The $\mathrm{N}_{\text {tot }}$ content revealed wavy changes during 1985-2003 in all parts of the lake (Fig. 2). Two $\mathrm{N}_{\text {tot }}$ content drops were revealed in L. Peipsi s.s. during the study years: the first was recorded in 1986-1989, the second in 1992-1995. The southern part of the lake was richer in $\mathrm{P}_{\text {tot }}$ and $\mathrm{N}_{\text {tot }}$ than the northern part. The difference in the $\mathrm{P}_{\text {tot }}$ content between L. Pihkva (and L. Lämmijärv) and L. Peipsi s.s. was mostly twofold (Table 1). The long-term trend of dissolved inorganic $\mathrm{P}\left(\mathrm{PO}_{4}-\mathrm{P}\right)$ and $\mathrm{N}$ compounds $\left(\mathrm{NH}_{4}-\mathrm{N}+\mathrm{NO}_{3}-\mathrm{N}+\mathrm{NO}_{2}-\mathrm{N}=\mathrm{DIN}\right)$ was clearly decreasing: an extremely high maximum in the mid-1970s was followed by a decrease up to the middle of the 1980s, thereafter a small rise was recorded in the 1990s (Figs. 1 and 2). The course of DIN was determined by the content of $\mathrm{NO}_{3}-\mathrm{N}$ and $\mathrm{NH}_{4}-\mathrm{N}$, whereas the content of $\mathrm{NO}_{2}-\mathrm{N}$ was negligible.
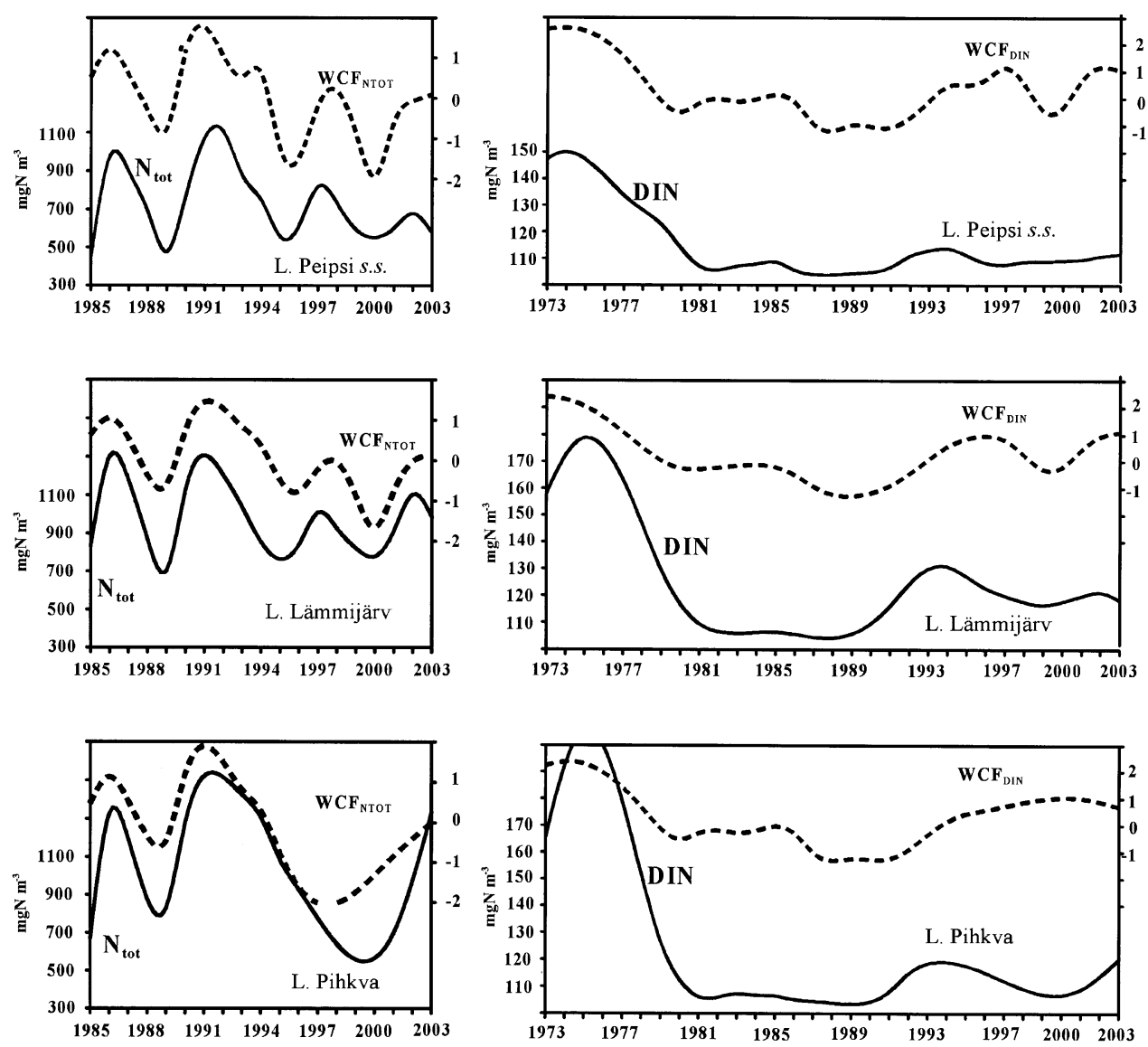

Fig. 2. Dynamics of WCF and the corresponding total and mineral nitrogen content in the lake parts. 


\section{Relationships between nutrients and the Water Condition Factor}

Correlations of all the eight water environment parameters with the corresponding WCF are presented in Table 2. The water level characteristics in WCF had a stronger effect on nutrients than water temperature did (Table 2). The influence of water temperature (WT) on the total concentration of phosphorus and nitrogen was insignificant; however, the influence of WT on the dissolved inorganic forms $\mathrm{PO}_{4}-\mathrm{P}$ and $\mathrm{DIN}$ was essential. The $\mathrm{P}_{\text {tot }}$ content was most significantly influenced by water level. All water level parameters showed a negative correlation with the $\mathrm{P}_{\text {tot }}$ content. In the case of lower WL the $\mathrm{P}_{\text {tot }}$ content was higher. The influence of WL on the $\mathrm{PO}_{4}-\mathrm{P}$ content was somewhat lower than on $\mathrm{P}_{\text {tot }}$. The most important factor was $\mathrm{WL}$ in the previous year, followed by WT in spring. The $\mathrm{N}_{\text {tot }}$ content was influenced by all WL parameters but WL in the sampling time and in autumn had the strongest effect. For the compounds of DIN, the most important factor in WCF was WL in the previous year. The strongest relationship $(r=0.51)$ was observed between WCF and the $\mathrm{N}_{\text {tot }}: \mathrm{P}_{\text {tot }}$ mass ratio. Figures 1-3 illustrate the long-term course of nutrients and WCF. The patterns found for $\mathrm{WCF}_{\mathrm{N}: \mathrm{P}}$ and $\mathrm{N}_{\text {tot }}: \mathrm{P}_{\text {tot }}$ as well as for $\mathrm{N}_{\text {tot }}$ and $\mathrm{WCF}_{\mathrm{Ntot}}$ were very similar (Figs. 2 and 3 ) throughout the entire study period. The course

Table 2. Correlations between the water variables and the corresponding WCF for the whole lake $\left(r_{\text {Peipsi }}\right)$ and for its parts $\left(r_{\text {Peipsi s.s. }}, r_{\text {Lämmijärv }}, r_{\text {Pihkva }}\right)$, and correlations of water environment parameters with the WCF. Notation: $\mathrm{WL}_{\mathrm{s}}$ - water level at sampling time, $\mathrm{WL}_{\text {mean }}$ - mean water level in sampling year, $\mathrm{WL}_{\mathrm{sp}}$ - water level in spring, $\mathrm{WL}_{\mathrm{au}}$ - water level in autumn, $\mathrm{WL}_{\mathrm{pr}}$ - mean water level in previous year, $\mathrm{WT}_{\mathrm{s}}$ - water temperature at sampling time, $\mathrm{WT}_{\mathrm{sp}}$ - water temperature in spring, $\mathrm{WT}_{\mathrm{au}}$ - water temperature in autumn

\begin{tabular}{lrrrrrrrrrrr}
\hline & $\mathrm{WCF}_{\text {Ptot }}$ & $\mathrm{WCF}_{\mathrm{Ntot}}$ & $\mathrm{WCF}_{\mathrm{N}: \mathrm{P}}$ & $\mathrm{WCF}_{\mathrm{PO} 4 \mathrm{P}}$ & $\mathrm{WCF}_{\mathrm{DIN}}$ & $\mathrm{WCF}_{\mathrm{FBM}}$ & $\mathrm{WCF}_{\mathrm{CY}}$ & $\mathrm{WCF}_{\mathrm{BAC}}$ & $\mathrm{WCF}_{\mathrm{CRYP}}$ \\
\hline WLs & -0.92 & 0.59 & 0.86 & -0.47 & -0.19 & -0.76 & -0.51 & -0.43 & 0.73 \\
WLmean & -0.57 & 0.37 & 0.51 & -0.51 & -0.50 & -0.39 & -0.35 & -0.10 & 0.55 \\
WLsp & -0.46 & 0.27 & 0.40 & -0.48 & -0.35 & -0.18 & -0.21 & 0.00 & 0.43 \\
WLau & -0.47 & 0.53 & 0.56 & -0.15 & -0.37 & -0.55 & -0.42 & -0.20 & 0.50 \\
WLpr & -0.40 & -0.25 & 0.08 & -0.89 & -0.84 & 0.14 & 0.08 & 0.13 & 0.34 \\
WTs & 0.08 & -0.17 & -0.11 & -0.22 & -0.24 & -0.17 & 0.56 & -0.84 & 0.63 \\
WTsp & -0.16 & -0.13 & 0.01 & -0.55 & 0.03 & 0.32 & 0.29 & 0.07 & -0.54 \\
WTau & -0.26 & -0.33 & -0.03 & -0.38 & -0.40 & -0.32 & -0.25 & -0.12 & 0.29 \\
\hline$r_{\text {Peipsi }}$ & 0.30 & 0.40 & 0.51 & 0.32 & 0.40 & 0.43 & 0.52 & 0.45 & 0.40 \\
$r_{\text {Peipsi s.s. }}$ & 0.36 & 0.41 & 0.53 & 0.35 & 0.33 & 0.44 & 0.54 & 0.46 & 0.40 \\
$r_{\text {Lämmijärv }}$ & 0.48 & 0.53 & 0.63 & 0.43 & 0.54 & 0.55 & 0.69 & 0.32 & 0.42 \\
$r_{\text {Pihkva }}$ & 0.47 & 0.54 & 0.66 & 0.32 & 0.56 & 0.70 & 0.68 & 0.54 & 0.61
\end{tabular}



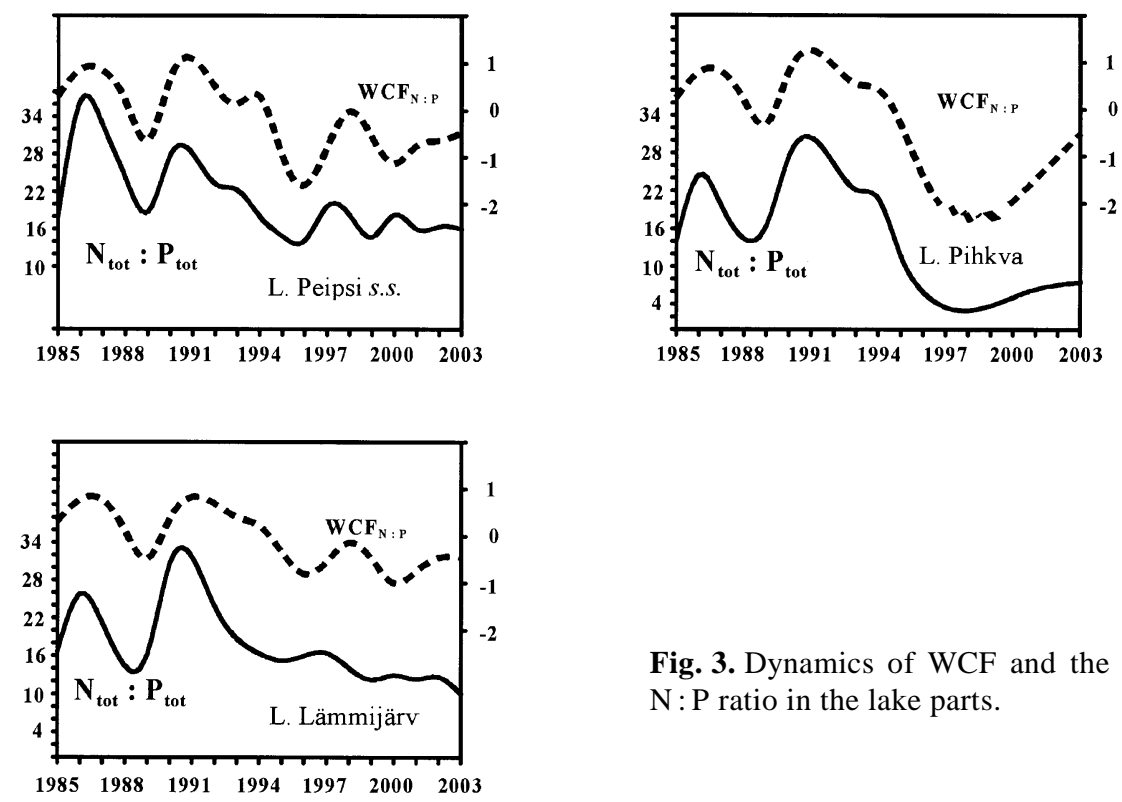

Fig. 3. Dynamics of WCF and the $\mathrm{N}: \mathrm{P}$ ratio in the lake parts.

of $\mathrm{WCF}_{\mathrm{Ptot}}$ and $\mathrm{P}_{\text {tot }}$ was opposite until the early $1990 \mathrm{~s}$, the reafter it was analogous (Fig. 1). In the shallower parts, L. Lämmijärv and L. Pihkva, the correlation between WCF and the nutrients was higher than in deeper L. Peipsi s.s. (Table 2).

\section{Phytoplankton dynamics}

The average summer biomass showed quite large fluctuations during the investigation period: up to 10 times in L. Peipsi s.s. and more than 20 times in L. Pihkva. Years rich in phytoplankton were observed at the end of the 1980s, in the 1990s, and particularly in 2000-2003; years poor in phytoplankton occurred in 1981-1987 (Fig. 4). All lake parts show an increasing trend of FBM and CY, particularly expressively in the southern parts (Figs. 4 and 5). After a heavy water bloom of CY in autumn 2000, A. islandica disappeared from the lake and a breakdown of BAC occurred (Fig. 6), except in L. Lämmijärv where the eutrophic A. ambigua started to dominate. Cryptophytes (CRYP) have quite a clear course analogous with that of WCF, particularly with water level (Fig. 7); however, the increase of trophy in L. Pihkva in the last years (Fig. 1) led to a drastic drop of this group.

As to WCF, CY are most affected by water temperature, whereas FBM, BAC, and CRYP not so substantially (Table 2). The WT at the sampling time was the most important for algal groups (contrary to CY and BAC), and water level 

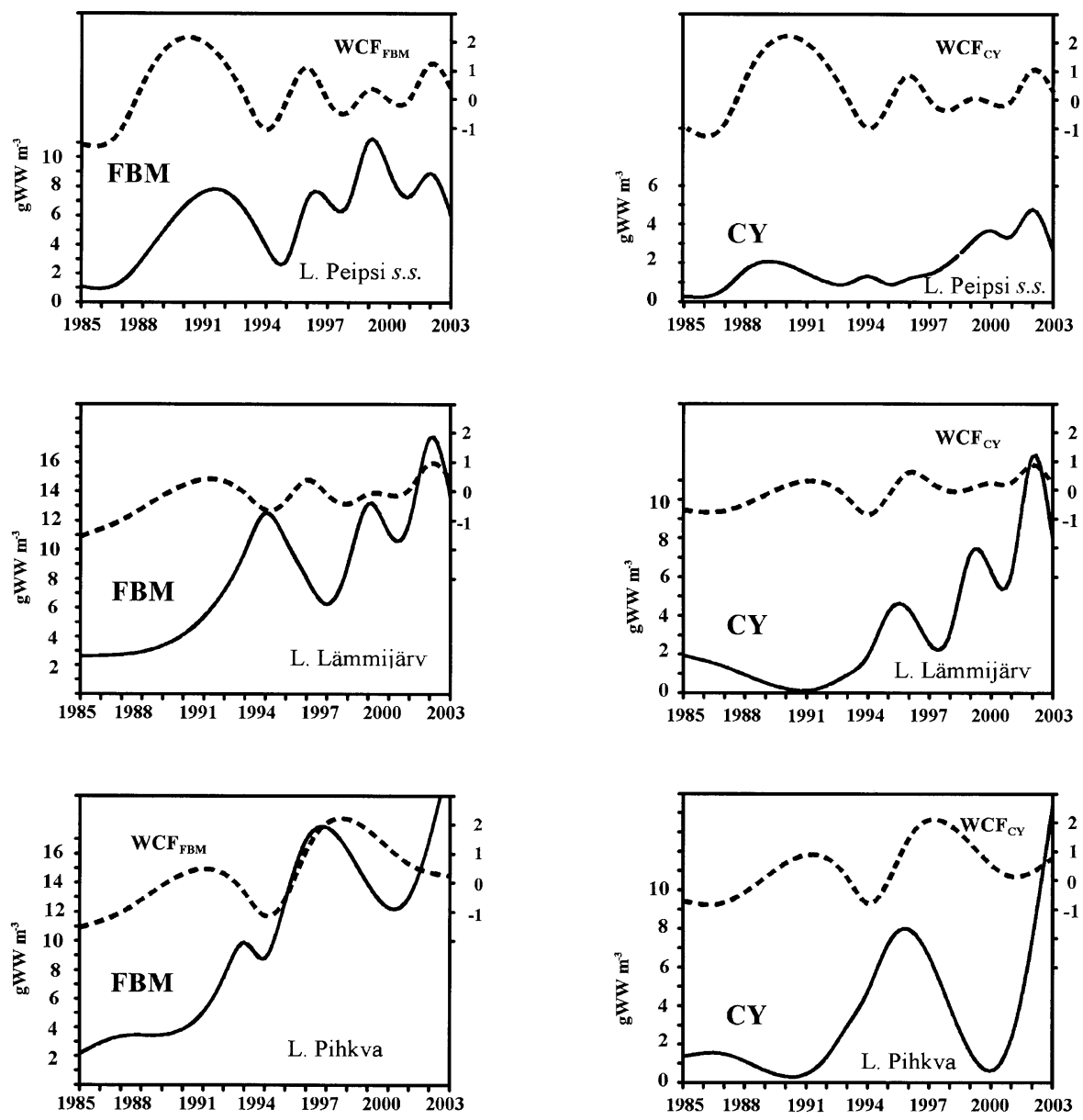

Fig. 4. Dynamics of WCF and the phytoplankton biomass (FBM) in the lake parts.

Fig. 5. Dynamics of WCF and the biomass of cyanobacteria $(\mathrm{CY})$ in the lake parts.

parameters for CRYP. The opposite course of cyanobacteria and the $\mathrm{N}: \mathrm{P}$ ratio is obvious (Figs. 3 and 5). The correlations between WCF and the phytoplankton values are evidently stronger in lakes Pihkva and Lämmijärv than in L. Peipsi s.s. (Table 2). It does not conform completely to Figs. 4-7: phytoplankton fluctuations are more extensive in the southern parts (lakes Lämmijärv and Pihkva), and in some cases the course is opposite to that in L. Peipsi s.s. Pearson correlation analysis of logarithmic values did not reveal any relations of FBM with water temperature (the opposite behaviour of CY and BAC!). CY and CRYP had a positive and $\mathrm{BAC}$ a negative correlation with temperature at the sampling time, and CY also in May. 

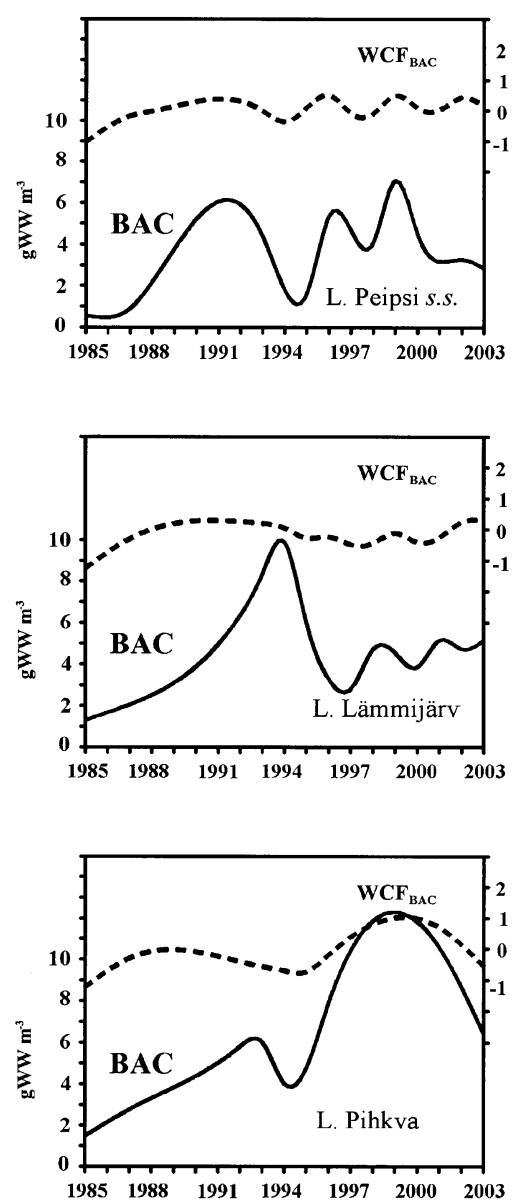

Fig. 6. Dynamics of WCF and the biomass of diatoms (BAC) in the lake parts.
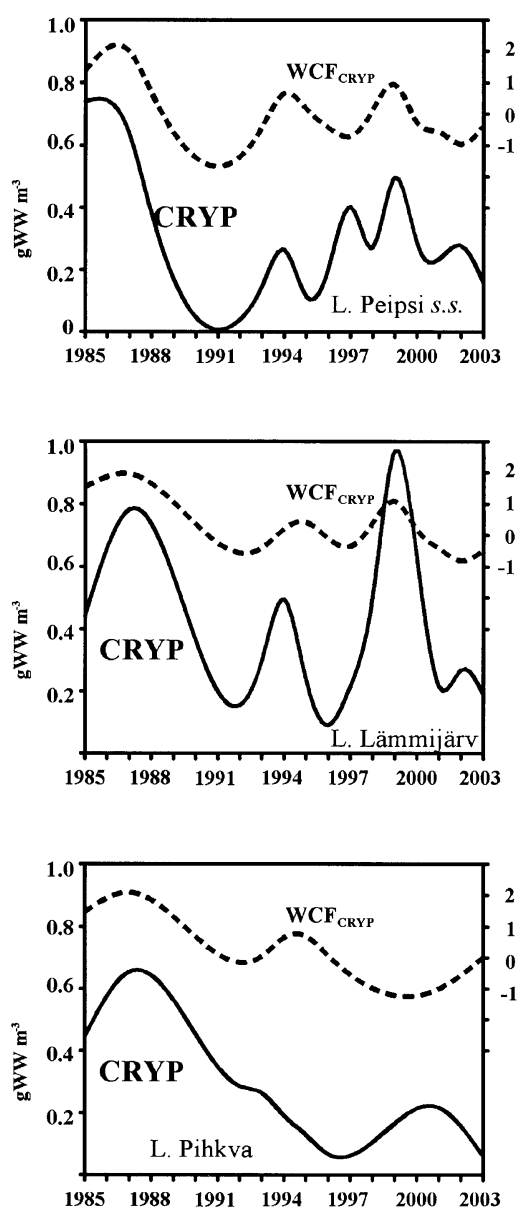

Fig. 7. Dynamics of $\mathrm{WCF}$ and the biomass of cryptophytes (CRYP) in the lake parts.

\section{DISCUSSION}

We ignored in this study the seasonal effects. As the water level and temperature also have seasonal dynamics, it is possible that some changes in water variables, which we explained here by changes in WCF, were actually the result of seasonal changes. Such misinterpretation is most probable for the plankton variables, which may have biologically programmed seasonality. Long-time fluctuations of weather conditions and phytoplankton biomass are considered to be related to variations in the solar radiation intensity and to trends in climate dynamics; however, in long-time data series (40 years) of L. Peipsi we found no correlations of phytoplankton biomass with the Sun's activity (Wolff number). In fact, periods of 
high biomass coincide with warm periods with low water in L. Peipsi (Laugaste et al., 2001) as well as in the other large Estonian lake, Võrtsjärv (Nõges et al., 2003). However, such regularities have not been detected in the neighbouring large deep lakes of Onega (Vislyanskaya, 1990) and Ladoga (Petrova et al., 1992). The enormous water mass in these lakes could be the reason. In the large and shallow Rybinsk Reservoir a strong influence of water level on the phytoplankton abundance was observed (Mineeva \& Litvinov, 1998). Like in L. Peipsi, in mesotrophic Lake Krasnoe (Punnusjärvi) blue-green algae were prevailing in warm and low-water years (1972-1973, some years in the 1990s), diatoms and dinoflagellates in the years with high water level in the middle of the 1980s (Trifonova \& Makartseva, 2003). Some diatoms such as A. islandica have their interior rhythm of growth, attaining high peaks in every four to six years and thus being relatively independent of weather conditions.

According to mean values, the increase in $\mathrm{P}_{\text {tot }}$ was especially great in L. Lämmijärv and L. Pihkva in recent years (Kangur et al., 2003). The polarity of L. Peipsi with respect of $\mathrm{P}_{\text {tot }}$ has grown more than with respect to $\mathrm{N}_{\text {tot. }}$. The $\mathrm{N}_{\text {tot }}: \mathrm{P}_{\text {tot }}$ mass ratio increased significantly in L. Peipsi s.s. at the beginning of the study period (1985-1988), thereafter, from 1990 onwards, a clear decrease occurred (Fig. 3). The average $\mathrm{N}_{\text {tot }}: \mathrm{P}_{\text {tot }}$ ratio in L. Peipsi s.s. was the highest (about 35) in 19861987 and the lowest (about 13) in 1995-1996. It is evident that the effect of water level is stronger in shallow lakes: in these lakes the reloading of phosphorus from the sediment in case of low water level is more intensive due to wind action, as observed in stormy days in L. Pihkva in August 2003 (authors' data). Despite the very high $\mathrm{P}_{\text {tot }}$ content at that time, the $\mathrm{CY}$ biomass did not exceed the common mean level. The rising and ending of bloom is usually caused by hydrophysical and weather conditions: strong wind can stop the bloom and cause the settling of algal colonies within a few hours. In shallower lakes Lämmijärv and Pihkva, the correlation between WCF and the nutrients was higher than in deeper L. Peipsi s.s. (Table 2).

It is well known that different algal groups require different water temperature for growth: cool water is necessary for chrysophytes and part of diatoms, and warm water for cyanobacteria. Water temperature has a direct effect through metabolism and reproduction intensity, and an indirect effect through nutrients (decomposition rate of debris by bacteria and intensity of internal loading) and the grazing of zooplankton. In shallow lakes the deterioration of water quality takes place in the warm period (Pettersson et al., 2003; Sondergaard et al., 2003). We must keep in mind the yearly different seasonal dynamics of WT: the years with close to mean WT may have very different seasonal temperatures which cause, for example, the domination of diatoms in cool summer and cyanobacteria in warm autumn. Carvalho \& Kirika (2003) did not find any relation between the phytoplankton chlorophyll $a$ content and annual mean WT. On the other hand, spring WT has a strong effect on summer chemical conditions (George et al., 2000), and phytoplankton biomass in summer depends on the total phosphorus content in spring 
(Krzywosz, 1999). In L. Peipsi, WT in May was important to CRYP as well as to the phosphorus $\left(\mathrm{PO}_{4}-\mathrm{P}\right)$ content (mean of vegetation period). Trifonova \& Makartseva (2003) note the determining effect of temperature on phytoplankton in the case of stable nutrient loading and the importance of water level to cyanobacteria. In L. Peipsi, WT at the sampling time was one of the most important components in WCF for all phytoplankton groups. Pettersson et al. (2003) compared seasonality of chlorophyll and nutrients in L. Erken in cold and warm periods and found that there were elevated phosphate, ammonium, and chlorophyll $a$ levels in August and autumn during the warm period. The authors explain these results with increasing activity of bacteria, which causes a higher uptake of oxygen and an intensive release of phosphate and ammonium from sediment to water.

In conclusion, in the Lake Peipsi dataset relationships between the water condition factor (combined water temperature and water level) and nutrients as well as phytoplankton groups were proved statistically. Temperature and water level have a synergized effect and evidently have an influence on phytoplankton via nutrients. The effect of water level, as well as the mechanical influence of wind and waves, is stronger in the shallower part, L. Pihkva.

\section{ACKNOWLEDGEMENTS}

The authors are grateful to the Estonian Science Foundation (grants 4986 and 6008) for financial support. The research was supported by the Estonian target financed project SF 0362483s03. In this study the data of the Estonian State monitoring programme were used. The contribution of the anonymous referees is highly appreciated.

\section{REFERENCES}

Carvalho, L. \& Kirika, A. 2003. Changes in shallow lake functioning: response to climate change and nutrient reduction. Hydrobiologia, 506-509, 789-796.

Eipre, T. F. 1983. Water level regime. In Lake Chudsko-Pskovskoe (Sokolov, A. A., ed.), pp. 42-52. Gidrometeoizdat, Leningrad (in Russian).

George, D. G., Talling, J. F. \& Rigg, E. 2000. Factors influencing the temporal coherence of five lakes in the English Lake District. Freshwater Biol., 43, 449-461.

Jaani, A. 1996. Hydrology and water balance of Lake Peipsi. Hydrobiologia, 338, 11-23.

Kangur, K., Möls, T., Milius, A. \& Laugaste, R. 2003. Phytoplankton response to changed nutrient level in Lake Peipsi (Estonia) in 1992-2001. Hydrobiologia, 506-509, 265-272.

Krzywosz, W. 1999. Relationships between trophic indicators and phytoplankton composition, biomass and photosynthetic activity in small eutrophic lakes. Polish J. Ecol., 47(1), 15-27.

Laugaste, R., Nõges, P., Nõges, T., Yastremskij, V. V., Milius, A. \& Ott, I. 2001. Algae. In Lake Peipsi. Flora and Fauna (Pihu, E. \& Haberman, J., eds.), pp. 31-49. Sulemees Publishers, Tartu.

Mäemets, H. \& Freiberg, L. 2004. Characteristics of reeds on Lake Peipsi and the floristic consequences of their expansion. Limnologica, 34(1-2), 83-89. 
Mineeva, N. M. \& Litvinov, A. S. 1998. Long-term variation of chlorophyll content in Rybinsk reservoir (Russia) in relation to its hydrological regime. NATO ASI Ser., 42, 159-183.

Nõges, T., Nõges, P. \& Laugaste, R. 2003. Water level as the mediator between climate change and phytoplankton composition in a large shallow temperate lake. Hydrobiologia, 506-509, 257-263.

Padisák, J. \& Koncsos, I. 2002. Trend and noise: long-term changes of phytoplankton in the Keszthely Basin of Lake Balaton, Hungary. Verh. Internat. Verein. Limnol., 28, 194-203.

Petersson, K., Grust, K., Weyhenmeyer, G. \& Blenckner, T. 2003. Seasonality of chlorophyll and nutrients in Lake Erken - effects of weather conditions. Hydrobiologia, 506-509, 75-81.

Petrova, N. A., Antonov, S. E. \& Protopopova, E. V. 1992. Structural and functional characteristics of phytoplankton. In Lake Ladoga. Criteria of the State of the Ecosystem (Petrova, N. A. \& Terzhevik, A., eds.), pp. 119-218. Nauka, Sankt-Peterburg (in Russian).

Reynolds, C. S. \& Petersen, A. C. 2000. The distribution of planktonic Cyanobacteria in Irish lakes in relation to their trophic states. Hydrobiologia, 424, 91-99.

Sondergaard, M., Jensen, J. P. \& Jeppesen, E. 2003. Role of sediment and internal loading of phosphorus in shallow lakes. Hydrobiologia, 506-509, 135-145.

Starast, H., Milius, A., Möls, T. \& Lindpere, A. 2001. Hydrochemistry of Lake Peipsi. In Lake Peipsi. Meteorology, Hydrology, Hydrochemistry (Nõges, T., ed.), pp. 97-131. Sulemees Publishers, Tartu.

Trifonova, I. S. \& Makartseva, E. S. 2003. Long-term dynamics of phyto- and zooplankton in mesotrophic Lake Krasnoe. In Lake Ecosystems: Biological Processes, Anthropogenic Transformation, Water Quality. Materials of the II International Scientific Conference (Mikheyeva, T. M., ed.), pp. 528-530. Belarus State University, Minsk (in Russian).

Vislyanskaya, I. G. 1990. Phytoplankton. In Ecosystem of Lake Onega and Trends of its Change (Kaufman, Z. S., ed.), pp. 183-192. Nauka, Leningrad (in Russian).

Wilander, A. \& Persson, G. 2001. Recovery from eutrophication: experiences of reduced phosphorus input to the four largest lakes of Sweden. Ambio, 30(8), 475-485.

\title{
Veetase ja veetemperatuur kui fütoplanktoni biomassi ja toiteainete sisaldust määravad faktorid Peipsi järves
}

\author{
Anu Milius, Reet Laugaste, Tõnu Möls, Marina Haldna ja Külli Kangur
}

Töös on kasutatud Peipsi järvest aastatel 1985-2003 kogutud andmeid. On käsitletud veetemperatuuri ja -taseme mõju fütoplanktoni tähtsamatele rühmadele ja toiteainete sisaldusele. Vaadeldavad faktorid olid nii veetase kui -temperatuur proovivõtu ajal, kevadel (mais) ja sügisel (oktoobris-novembris), lisaks veetase kogu vegetatsiooniperioodi jooksul nii samal kui ka eelneval aastal. Need koondati üheks keskkonnafaktoriks (WCF), mis kanoonilisel analüüsil arvutati eraldi iga fütoplanktoni komponendi ja iga toitaine kohta. Sellega selgitati, millisel määral on need sõltuvad WCF-i koostisosadest. Selgus, et toitesooladele on peamine mõju veetasemel, kuna temperatuur on oluline vaid nende mineraalsetele vormidele. Fütoplanktonile mõjub nii veetase kui temperatuur, kusjuures kõige rohkem on mõjutatud sinivetikad. Keskkonnafaktori korrelatsioonid fütoplanktoni ja toiteainete suhtes olid tugevamad järve madalates osades (Pihkva ja Lämmijärves) ja nõrgemad Peipsi s.s. sügavamas põhjaosas. 